\title{
The use of biomarkers in the diagnosis and treatment of obstruction of the upper urinary tract in children
}

\author{
Zuzana Seifriedova ${ }^{a}$, Hana Flogelova ${ }^{b}$, Jan Sarapatkaa ${ }^{a}$ Oldrich Smakal ${ }^{a}$, Vladimir Student Jr. ${ }^{a}$
}

Antenatal hydronephrosis, dilatation of the upper urinary tract (UUTD), is a common finding on prenatal ultrasound. One of the most common causes is ureteropelvic junction (UPJ) obstruction. Although such prenatally diagnosed UUTD resolves spontaneously in most newborns, further examination of these children is advocated to prevent possible irreversible kidney damage, and ultrasound is mainly used for this. If the dilatation persists or becomes symptomatic, it is necessary to proceed to other relatively demanding and invasive diagnostic examinations for these small patients, where the question of the right timing of indications for possible surgical solutions is still unclear. For this reason, various biomarkers have been investigated in a number of clinical trials as potential mini-invasive diagnostic tools for determining when upper urinary tract dilatation in such children poses a threat to the developing kidneys and they should be operated on, and vice versa, when to proceed conservatively. The aim of this article is to review the findings on and current issues with the use of biomarkers in the diagnosis and treatment of UPJ obstruction in children.

Key words: hydronephrosis, obstruction, ureteropelvic junction, biomarkers

Received: May 13, 2021; Revised: November 28, 2021; Accepted: January 21, 2022; Available online: Fabruary 3, 2022

https://doi.org/10.5507/bp.2022.002

(c) 2022 The Authors; https://creativecommons.org/licenses/by/4.0/

${ }^{a}$ Department of Urology, University Hospital Olomouc and Faculty of Medicine and Dentistry, Palacky University Olomouc, Czech Republic ${ }^{b}$ Department of Pediatrics, Faculty of Medicine and Dentistry, Palacky University Olomouc and University Hospital Olomouc, Czech Republic Corresponding author: Vladimir Student Jr., e-mail: vladimir.student2@fnol.cz

\section{INTRODUCTION}

Antenatal hydronephrosis with UPJ obstruction is a congenital malformation associated with a restriction in the outflow of urine, which is defined according to the European Association of Urology Guidelines as an impaired outflow of urine from the renal pelvis to the proximal ureter with subsequent dilatation of the renal drainage system and risk of renal impairment ${ }^{1}$.

Unilateral obstruction can lead to progressive deterioration of renal function in $20-40 \%$ of cases, according to available studies. In these patients, treatment should be initiated early, with the main caveat being a lack of valid markers with the ability to predict in whom renal impairment will occur ${ }^{2}$.

The UPJ obstruction with incidence 1:1500 newborns, and a male-to-female ratio of 2:1 ( ref. $^{3}$ ). UUTD is diagnosed prenatally in ultrasonographic (US) screening, most often in the 28th week, and confirmed postnatally. Cases that are not detected through prenatal screening are most often postnatally manifested by urinary tract infections, failure to thrive, or pain. Although in most neonates, such prenatally diagnosed upper urinary tract dilatation (UUTD) resolves spontaneously, there is a significant number of cases in which the ultrasound deteriorates, and there is a high risk of progression to permanent loss of renal function

The main task of pediatric urologists is to distinguish patients who require surgery to maintain kidney function from those who will probably spontaneously correct.
Common diagnostic procedures for examining children with UPJ obstruction include ultrasonography of the urinary tract, dynamic diuretic scintigraphy of the kidneys (99mTc-MAG 3), voiding cystourethrography (VCUG), and biochemical parameters of renal function, especially serum creatinine. Significant UPJ obstruction, which is an indication for surgery, is determined based on ultrasound findings, dynamic diuretic MAG 3 scintigraphy, and/or symptomatology (persistent hip pain, urinary tract infections). Criteria include (I) decrease in relative renal function $<40 \%$, (II) decrease in relative renal function by more than $10 \%$ in subsequent MAG 3 follow-up, (III) impaired drainage after furosemide administration, (IV) ultrasound evidence of anteroposterior diameter enlargement of the pelvis, (V) dilatation of renal pelvis III.-IV. degrees and symptomatic hydronephrosis ${ }^{4}$.

In many cases, a borderline finding may be encountered according to the above diagnostic examinations. It is not easy to determine whether patients will benefit from surgery, or whether it is possible to continue monitoring them and proceed conservatively. In the event of a deterioration of the findings, it is very important to make a timely decision when the risk of renal damage is such that surgical treatment is indicated. A crucial aspect of conservative monitoring is repeated diuretic MAG 3 scintigraphy. The total time of the radionuclide examination of the kidneys is about $45 \mathrm{~min}$. The radiopharmaceutical is administered intravenously and it is therefore very burdensome for children, especially in infancy and toddler ages. Due to the invasiveness of these examinations and the described 
limitations of general criteria for indicating surgical treatment of UPJ obstruction, a suitable diagnostic marker predicting future kidney disease is sought, to accurately and timely evaluate the need for surgery in the case of obstruction. The value of urinary biomarkers, which appear to be a possible minimally invasive diagnostic tool to distinguish between obstructive and non-obstructive UUTD, is currently being investigated.

The aim of this article is to review the facts and current issues in the use of biomarkers in the diagnosis and treatment of upper urinary tract (UUT) obstruction in children.

\section{BIOMARKERS OF RENAL DAMAGE}

A biomarker is defined as a parameter that can be measured objectively and is evaluated as an indicator of both normal physiological and pathogenic processes and/ or pharmacological responses to a therapeutic intervention $^{5}$. Animal models have provided us with new insights into the cellular response to developing kidney obstruction, helping us to identify individual molecules that elicit a pathogenic response to renal damage, mediators of interstitial inflammation, tubular apoptosis, and fibrosis.

Recently, proteomics - a science that studies proteins, their properties, and functions, has become a key diagnostic and prognostic tool for many clinical specialists. Today, we can understand and explain the cellular and molecular nature of individual diseases, while the proteins analyzed can be used to determine the disease in its early stages. The etiopathogenesis of renal damage and the progression of renal insufficiency in obstructive nephropathy consists of several processes at the cellular and molecular level. These include the hemodynamic response of the kidneys, ie. decrease in blood flow mainly through the renal cortex, decrease in capillary wall per- meability, infiltration of the interstitium by macrophages, reflux of filtrate through the damaged tubule wall into the interstitium, dilatation of renal tubules and apoptosis and accumulation of peeled tubular cells in the lumen of the renal tubules. This process proceeds under the influence of various enzymes, cytokines, chemokines, growth factors, signaling molecules, and genes. In recent years, these findings have identified several molecules that could potentially be used as biomarkers with promising results in both diagnosis and treatment, as well as a prognostic factor in children with UPJ obstruction.

\section{CLINICAL STUDIES EVALUATING BIOMARKERS IN UPJ OBSTRUCTION}

Dozens of clinical studies on biomarkers of UPJ obstruction in children have been published since 2000 . Most biomarkers are analyzed in urine in these studies but some investigate serum concentrations. Proteins are quantified using commercially available ELISA kits (human sandwich enzyme-linked immunosorbent assay). Included in this review article are studies that examined biomarkers in urine samples in children under 18 years of age with unilateral or bilateral evidence of UPJ obstruction compared to healthy children (control group) and/ or children with dilatation of the renal collecting system without obstruction (conservatively treated group). An overview of biomarkers is summarized in Table 1.

Most studies have addressed only unilateral UPJ obstruction, although some publications discuss bilateral obstruction. In most cases, the authors compared the levels of biomarkers in patients who underwent pyeloplasty (operated group) with patients with upper tract dilatation without proven UPJ obstruction (group monitored or conservatively treated) and healthy people without dilation (control group). Other studies compared biomarker levels

Table 1. Biomarkers clinically studied in UPJ obstruction.

\begin{tabular}{ll}
\hline Urinary biomarker & Clinical studies (ref.) \\
\hline neutrophil gelatinase-associated lipocalin (NGAL) & $(6-14)$ \\
monocyte chemotactic peptide-1 (MCP1) & $(6,9,28-32)$ \\
transforming growth factor $\beta 1$ (TGFß1) & $(6,23-27)$ \\
interleukin 6 (IL-6) & $(6)$ \\
carbohydrate antigen 19-9 (CA19-9) & $(14-22)$ \\
epidermal growth factor (EGF) & $(25,29,31,33,35)$ \\
kidney injury molecule 1 (KIM1) & $(7,9,10,12,33,34)$ \\
antimicrobial peptides (AMPs) - B defense 1 (BD1) & $(40)$ \\
cathelicidin (LL37) & $(40)$ \\
hepatocarcinoma-intestine-pancreas/pancreatitis-associated protein (HIP/PAP) & $(40)$ \\
Chemokine (C-C motif) ligand 5 (CCL5) also known as RANTES & $(29,30,36)$ \\
$\quad$ (regulated upon activation, normal T cell expressed and presumably secreted) & $(38-39)$ \\
N-acetyl- $\beta$-D-glucosaminidase (NAG) & $(41)$ \\
prostaglandin reductase 1 (PTGR1) & $(41)$ \\
ficolin 2 (FCN2) & $(41)$ \\
quinolinate phosphoribosyl transferase (QPRT) & $(41)$ \\
immunoglobulin superfamily containing leucine-rich repeat protein (ISLR) & \\
$\quad$ a vascular cell adhesion molecule 1 (VCAM1) &
\end{tabular}


only in the operated children vs. healthy children without dilatation or surgery vs. conservative treatment. Other studies also compared patients with dilatation without distinction between operated and non-operated patients with a group of healthy children.

Most investigations focused on the evaluation of the outcome of the surgical solution, ie. pyeloplasty using urinary biomarker levels that compared pre-and postoperative values. Others looked at the correlation between the preoperative concentration of biomarkers and the anteroposterior dimension of the renal pelvis according to ultrasound, or the correlation between the preoperative level of biomarkers and relative renal function according to the scintigraphic examination of the kidneys. Table 2 summarizes the data of 29 studies published between 2000-2021 and included in this review.

\section{THE MOST FREQUENTLY INVESTIGATED BIOMARKERS, ANALYSIS, AND COMPARISON OF STUDY RESULTS}

\section{NGAL}

NGAL is an organ-specific protein that belongs to the lipocalin family of proteins. It is secreted by various tissues and subsequently reabsorbed by endocytosis through the epithelium in the proximal renal tubules. It is expressed in urine and detectable after toxic and ischemic tissue damage. It is also considered an early marker of renal damage in the event of an obstruction.

Prospective clinical studies in children with severe hydronephrosis due to UPJ obstruction have shown significantly higher levels of NGAL (normalized to urinary creatinine) in the urine collected from the bladder of sick compared to healthy children ${ }^{6-12}$. In a study by Madsen et al. ${ }^{13}$ no difference in urine collected from the bladder was found. However, a difference in NGAL levels was found in urine collected perioperatively from the renal pelvis in patients with UPJ obstruction compared to "bladder" NGAL in patients as well as NGAL levels in healthy children when determined from urinated urine. This was subsequently confirmed in a study by Cost et al. ${ }^{11}$. According to some other studies ${ }^{9,13,12}$, NGAL levels have a decreasing tendency 3-6 months after surgery. In eight studies ${ }^{6-13}$, preoperative NGAL values differed significantly in patients with evidence of UPJ obstruction from healthy children, and in two studies ${ }^{10,12}$ in the group of upper tract dilation without obstruction. Fendereski et al. ${ }^{14}$ reported a significant correlation between renal impairment, urinary NGAL, and CA 19-9.

\section{CA 19-9}

CA 19-9 is a tumor-associated marker belonging to the family of carbohydrate antigens. It is not tumor or organspecific. Elevated serum levels are found in malignancies such as pancreatic cancer, gastric cancer, colorectal cancer, and bile duct cancer. This protein is expressed in various tissues with glandular epithelium. Elevated levels of CA 19-9 have also been observed in both urothelial tumors and non-tumor conditions in secondary hydronephrosis due to ureterolithiasis obstruction ${ }^{15-19}$.

Three studies ${ }^{20-22}$ reported significantly higher preoperative levels of CA 19-9 in a group of patients with evidence of UPJ obstruction compared to a healthy control group. According to Atara et al. ${ }^{21}$, the values of this biomarker were significantly increased in patients with UPJ obstruction before surgery compared to patients with upper tract dilation without evidence of obstruction. These authors as well as Kajbafzadeha et al. ${ }^{22}$ found these values in the group operated on, decreased significantly three months after the operation. According to the most recent study by Fendereski et al. ${ }^{14}$, who studied a cohort of 161 patients and had a total follow-up of 2 years, CA 19-9 appears to be a promising predictor of the need for surgery compared to other biomarkers studied (NGAL and KIM 1). This was a well-designed clinical trial, in which the participants were equally divided into two groups (surgery vs. conservative management) and there were no differences in age and sex between the groups. A significant correlation between impaired renal function and urinary CA 19-9 and NGAL was also reported. The results of this research could pave the way for wider clinical use of these markers.

\section{TGF $\beta 1$}

TGF $\beta 1$ is a polypeptide belonging to the superfamily of cytokines. This protein provides several cellular functions, including control of cell growth, cell proliferation, differentiation, and apoptosis. It plays a major role in the process of renal fibrosis. Increased TGF $\beta 1$ synthesis in the kidney is associated with collagen accumulation and scarring, which by degrees leads to the development of advanced chronic renal disease. There is an assumption that the level of this marker in urine could be used as a non-invasive tool to evaluate the progression of kidney disease and monitor the success of the surgery.

In three studies ${ }^{23-25}$, TGF $\beta 1$ levels measured in urine were significantly elevated before surgery in operated children with UPJ obstruction compared to a healthy control group. In contrast, one of the first published studies to investigate biomarkers in the diagnosis and treatment of UPJ obstruction in children in 1997 Palmer et al. ${ }^{26}$ and more recently Yu et al. ${ }^{6}$ found no difference between these groups. According to El-Sherbiny et al. ${ }^{27}$, preoperative levels of this biomarker were significantly higher in operated children with confirmed UPJ obstruction compared to patients observed for KPS dilation without obstruction. Three months after the operation, a declining trend of the biomarker was recorded, which was statistically insignificant. In contrast, Sager et al. ${ }^{24}$ and Taha et al. ${ }^{25}$ reported a significant decrease in postoperative biomarker values compared to preoperative concentrations.

\section{MCP1}

MCP1 is a chemokine protein that mediates monocyte chemotaxis. In the case of obstruction, its expression at the level of the renal tubules appears to be directly associated with the accumulation of these inflammatory cells within the interstitial space. Thus, urinary excretion of MCP1 
Table 2. Pediatric clinical studies on urinary biomarkers in UPJ obstruction.

\begin{tabular}{|c|c|c|c|c|c|c|c|}
\hline Author & Year & Biomarker & $\begin{array}{l}\text { No. of } \\
\text { participants }\end{array}$ & $\begin{array}{l}\text { Age of partici- } \\
\text { pants (range) }\end{array}$ & Source & Follow up & Ref. \\
\hline Yu et al. & 2019 & $\begin{array}{l}\text { NGAL, TGF } \beta 1 \text {, } \\
\text { MCP1, IL-6 }\end{array}$ & $\begin{array}{l}17 \mathrm{SG} \\
17 \mathrm{CG}\end{array}$ & 11-192 months & Bladder & ND & 6 \\
\hline Bienias et al. & 2018 & NGAL, KIM1 & $\begin{array}{l}45 \mathrm{SG} \\
21 \mathrm{CG}\end{array}$ & $2-17$ years & Bladder & ND & 7 \\
\hline Gupta et al. & 2018 & $\begin{array}{l}\text { NGAL, HIP / } \\
\text { PAP, BD-1, LL-37 }\end{array}$ & $\begin{array}{l}30 \mathrm{SG} \\
15 \mathrm{CG}\end{array}$ & $0.3-18.4$ years & Bladder & ND & 8 \\
\hline Karakus et al. & 2016 & $\begin{array}{l}\text { NGAL, MCP1, } \\
\text { KIM1 }\end{array}$ & $\begin{array}{l}13 \mathrm{SG} \\
14 \mathrm{NSG} \\
9 \mathrm{CG}\end{array}$ & $6-77$ months & Bladder & $\begin{array}{l}\text { Postoperative } 3^{\text {rd }}, 6^{\text {th }} \\
\text { month and } 3^{\text {rd }} \text { year }\end{array}$ & 9 \\
\hline Noyan et al. & 2015 & NGAL, KIM1 & $\begin{array}{l}26 \mathrm{SG} \\
36 \mathrm{NSG} \\
20 \mathrm{CG}\end{array}$ & $1-48$ months & Bladder & ND & 10 \\
\hline Cost et al. & 2013 & NGAL & $25 \mathrm{SG}$ & $0.12-18.7$ years & $\begin{array}{l}\text { Bladder, } \\
\text { pelvis }\end{array}$ & ND & 11 \\
\hline Wasilewska et al. & 2011 & NGAL, KIM1 & $\begin{array}{l}20 \mathrm{SG} \\
20 \mathrm{NSG} \\
25 \mathrm{CG}\end{array}$ & $0.16-17$ years & $\begin{array}{l}\text { Bladder, } \\
\text { pelvis }\end{array}$ & Postoperative $3^{\mathrm{dd}}$ month & 12 \\
\hline Madsen et al. & 2012 & NGAL & $\begin{array}{l}24 \mathrm{SG} \\
13 \mathrm{CG}\end{array}$ & $3-5$ years & $\begin{array}{l}\text { Bladder, } \\
\text { pelvis }\end{array}$ & $\begin{array}{l}\text { Postoperative day } 1 \text {, } \\
3^{\text {rd }} \text { week, } 3^{\text {rd }} \text { month, } 1 \\
\text { year }\end{array}$ & 13 \\
\hline Fendereski et al. & 2021 & $\begin{array}{l}\text { NGAL, CA19-9, } \\
\text { KIM1 }\end{array}$ & $\begin{array}{l}79 \mathrm{SG} \\
82 \mathrm{CG}\end{array}$ & $\begin{array}{l}\text { Median for SG } \\
6.0 \text { and for } C G \\
7.5 \text { months, old- } \\
\text { est } 5 \text { years }\end{array}$ & Bladder & ND & 14 \\
\hline Nabavizadeh et al. & 2019 & CA19-9 & $\begin{array}{l}34 \mathrm{SG} \\
24 \text { delayed SG } \\
54 \mathrm{CG}\end{array}$ & $\begin{array}{l}\text { Mean }(\mathrm{SD}) \\
18.6( \pm 3.3) \\
\text { months }\end{array}$ & Bladder & ND & 20 \\
\hline Atar et al. & 2015 & CA19-9 & $\begin{array}{l}17 \mathrm{SG} \\
17 \mathrm{NSG} \\
21 \mathrm{CG}\end{array}$ & $\begin{array}{l}\text { Mean }(\mathrm{SD}) \\
15.3( \pm 14.6) \\
\text { months }\end{array}$ & Bladder & $\begin{array}{l}\text { Postoperatively } 3^{\text {rd }} \\
\text { month }\end{array}$ & 21 \\
\hline Kajbafzadeh et al. & 2010 & CA19-9 & $\begin{array}{l}27 \mathrm{SG} \\
27 \mathrm{CG}\end{array}$ & $0.5-98$ months & $\begin{array}{l}\text { Bladder, } \\
\text { pelvis }\end{array}$ & $\begin{array}{l}\text { Postoperatively } 3^{\text {rd }} \text { and } \\
9^{\text {th }} \text { month }\end{array}$ & 22 \\
\hline Merikhi et al. & 2014 & $\mathrm{TGF} \beta 1$ & $\begin{array}{l}25 \mathrm{SG} \\
25 \mathrm{CG}\end{array}$ & $\begin{array}{l}\text { SG: Mean }(\mathrm{SD}) \\
7.4( \pm 4.5) \text { years } \\
\text { CG: Mean }(\mathrm{SD}) \\
6.8( \pm 5.6) \text { years }\end{array}$ & Bladder & ND & 23 \\
\hline Sager et al. & 2009 & TGF $\beta 1$ & $\begin{array}{l}19 \mathrm{SG} \\
19 \mathrm{CG}\end{array}$ & $\begin{array}{l}5 \text { months }-17.6 \\
\text { years }\end{array}$ & Bladder & $\begin{array}{l}\text { Postoperatively } 3^{\text {rd }} \text { and } \\
5^{\text {th }} \text { month }\end{array}$ & 24 \\
\hline Taha et al. & 2007 & TGF $\beta 1$, EGF & $\begin{array}{l}35 \mathrm{SG} \\
30 \mathrm{CG}\end{array}$ & $0.5-13$ years & Bladder & $\begin{array}{l}\text { Postoperatively } 1^{\text {st }}, \\
2^{\text {nd }}, 3^{\text {rd }}, 6^{\text {th }}, 9^{\text {th }}, \text { and } 12^{\text {th }} \\
\text { month }\end{array}$ & 25 \\
\hline Palmer et al. & 1997 & TGF $\beta 1$ & $\begin{array}{l}13 \mathrm{SG} \\
19 \mathrm{CG}\end{array}$ & $1-11$ years & $\begin{array}{l}\text { Bladder, } \\
\text { pelvis }\end{array}$ & ND & 26 \\
\hline El-Sherbiny et al. & 2002 & TGF $\beta 1$ & $\begin{array}{l}15 \mathrm{SG} \\
11 \mathrm{CG}\end{array}$ & $\begin{array}{l}\text { Mean }(\mathrm{SD}) \\
5.2( \pm 4.7) \text { years }\end{array}$ & $\begin{array}{l}\text { Bladder, } \\
\text { pelvis }\end{array}$ & $\begin{array}{l}\text { Postoperatively } 3^{\text {rd }} \\
\text { month }\end{array}$ & 27 \\
\hline Sadeghi-Bojd et al. & 2018 & MCP1 & $\begin{array}{l}20 \mathrm{SG} \\
20 \mathrm{NSG} \\
30 \mathrm{CG}\end{array}$ & $\begin{array}{l}\text { Mean }(\mathrm{SD}) \\
23.5( \pm 21.8) \\
\text { months }\end{array}$ & Bladder & ND & 28 \\
\hline Madsen et al. & 2013 & $\begin{array}{l}\text { MCP1, EGF, } \\
\text { CCL5/RANTES }\end{array}$ & $\begin{array}{l}28 \mathrm{SG} \\
13 \mathrm{CG}\end{array}$ & $3.5-15$ years & $\begin{array}{l}\text { Bladder, } \\
\text { pelvis }\end{array}$ & $\begin{array}{l}\text { Postoperatively } 1^{\text {st }} \text { day, } \\
3^{\text {rd }} \text { week, } 3^{\text {rd }} \text { month, } 1 \\
\text { year }\end{array}$ & 29 \\
\hline Taranta-Janusz et al. & 2012 & $\begin{array}{l}\text { MCP1, CCL5/ } \\
\text { RANTES }\end{array}$ & $\begin{array}{l}15 \mathrm{SG} \\
21 \mathrm{NSG} \\
19 \mathrm{CG}\end{array}$ & $0.08-8$ years & $\begin{array}{l}\text { Bladder, } \\
\text { pelvis }\end{array}$ & $\begin{array}{l}\text { Postoperatively } 3^{\text {rd }} \\
\text { month }\end{array}$ & 30 \\
\hline Grandaliano et al. & 2000 & $\mathrm{MCP} 1, \mathrm{EGF}$ & $\begin{array}{l}24 \mathrm{SG} \\
15 \mathrm{CG}\end{array}$ & $2-156$ months & $\begin{array}{l}\text { Bladder, } \\
\text { pelvis }\end{array}$ & $\begin{array}{l}\text { Postoperatively in } 2-4 \\
\text { months }\end{array}$ & 31 \\
\hline Mohammadjafari et al. & 2014 & MCP1 & $\begin{array}{l}24 \mathrm{SG} \\
18 \mathrm{NSG}\end{array}$ & $\begin{array}{l}\text { Mean } 4.2 \\
\text { months }\end{array}$ & Bladder & ND & 32 \\
\hline
\end{tabular}


Table 2. (Continued)

\begin{tabular}{|c|c|c|c|c|c|c|c|}
\hline Author & Year & Biomarker & $\begin{array}{l}\text { No. of } \\
\text { participants }\end{array}$ & $\begin{array}{l}\text { Age of partici- } \\
\text { pants (range) }\end{array}$ & Source & Follow up & Ref. \\
\hline Mohammadjafari et al. & 2014 & KIM1, EGF & $\begin{array}{l}24 \mathrm{SG} \\
18 \mathrm{NSG} \\
17 \mathrm{CG}\end{array}$ & NA & Bladder & ND & 33 \\
\hline Gerber et al. & 2016 & KIM1, NGAL & $\begin{array}{l}12 \mathrm{SG} \\
12 \mathrm{CG}\end{array}$ & $4-240$ months & Bladder & ND & 34 \\
\hline Li et al. & 2012 & EGF & $\begin{array}{l}12 \mathrm{SG} \\
33 \mathrm{NSG}\end{array}$ & $4.3-18.9$ months & Bladder & $\begin{array}{l}\text { Postoperatively } 3 \text { times: } \\
\text { in first } 6 \text { months, in } \\
6-12 \text { months and in } \\
1-2 \text { years }\end{array}$ & 35 \\
\hline Shokeir et al. & 2009 & NAG & $\begin{array}{l}15 \mathrm{SG} \\
15 \mathrm{NSG}\end{array}$ & $\begin{array}{l}9 \text { months - } \\
12 \text { years }\end{array}$ & Bladder & $\begin{array}{l}\text { Postoperatively } 3^{\text {rd }}, 9^{\text {th }} \text {, } \\
\text { and } 15^{\text {th }} \text { month }\end{array}$ & 38 \\
\hline Taha et al. & 2007 & NAG & $\begin{array}{l}35 \mathrm{SG} \\
15 \mathrm{NSG}\end{array}$ & $\begin{array}{l}6 \text { months - } \\
12 \text { years }\end{array}$ & Bladder & $\begin{array}{l}\text { Postoperatively } 1^{\text {st }}, \\
2^{\text {nd }}, 3^{\text {rd }}, 6^{\text {th }}, 9^{\text {th }}, \text { and } 12^{\text {th }} \\
\text { month }\end{array}$ & 39 \\
\hline Gupta et al. & 2020 & $\begin{array}{l}\text { BD 1, HIP/PAP, } \\
\text { LL37 }\end{array}$ & $\begin{array}{l}13 \mathrm{SG} \\
15 \mathrm{CG}\end{array}$ & $0.4-18.4$ years & Bladder & $\begin{array}{l}\text { Postoperatively once } \\
\text { (done in } 7.8-45.3 \\
\text { months) }\end{array}$ & 40 \\
\hline Devarakonda et al. & 2020 & $\begin{array}{l}\text { PTGR1, FCN2, } \\
\text { QPRT, VCAM1 }\end{array}$ & $\begin{array}{l}21 \mathrm{SG} \\
22 \mathrm{CG}\end{array}$ & $\begin{array}{l}\text { SG: Average } \\
(\mathrm{SD}) \\
8.3( \pm 3.0) \\
\text { months } \\
\text { CG: Average } \\
(\mathrm{SD}) \\
6.0( \pm 3.8) \\
\text { months }\end{array}$ & Bladder & ND & 41 \\
\hline
\end{tabular}

(SG) surgical group with UPJ obstruction, (NSG) nonsurgical group, treated conservatively, (CG) healthy control group, (ND) not done, (NA) not available

may be associated with the rate of monocyte infiltration and subsequent progression of interstitial renal fibrosis.

All studies have shown a high correlation between MCP1 levels in urine with the extent of tubular atrophy and interstitial fibrosis, and have revealed that urinary concentrations of this protein can successfully differentiate not only children with UPJ obstruction who need intervention, from healthy control children but also from control children with upper tract dilation without obstruction, which can be treated conservatively. Significantly higher levels of MCP1 in preoperative samples compared to controls were reported by some studies ${ }^{6,9,28-31}$. Some authors ${ }^{9,28,30,32}$ pointed to higher concentrations of MCP1 in the group operated with UPJ obstruction compared to the group of patients with upper tract dilation without obstruction. According to Grandaliano et al. ${ }^{31}$, there was a significant decrease in biomarker levels between two and four months after the procedure compared to preoperative values, and this marker could thus be useful for long-term follow-up of patients in the postoperative period.

\section{KIM 1}

KIM 1 is a type I transmembrane glycoprotein. As it cannot be detected in healthy children but is highly expressed and released by damaged epithelial cells of the proximal tubules until they are completely restored, it could be used as an early and sensitive urinary biomarker of renal impairment in obstructive nephropathy.

According to Bienias et al. ${ }^{7}$, Karakus et al. ${ }^{9}$ and
Wasilewska et al. ${ }^{12}$, KIM1 urinary concentrations in patients with UPJ obstruction before surgery were significantly increased compared to healthy individuals and according to Mohammadjafari et al. ${ }^{33}$ and Wasilewska et al. ${ }^{12}$ even compared to a group monitored with upper tract dilation without obstruction. However, Noyan et al. ${ }^{10}$ and Gerber et al. ${ }^{34}$ found no difference in urinary KIM1 levels in children with UPJ obstruction compared with healthy children. Similarly, no significant difference was found between patients with UPJ obstruction and dilation without obstruction in Karakus et al. ${ }^{9}$ and Noyan et al. ${ }^{10}$.

\section{EGF}

EGF is a growth factor polypeptide that plays a key role in normal tubulogenesis. It has been shown to affect the modulation of tubular cell growth and the tissue response in the kidney during the interstitial process. However, the evaluation of urinary EGF levels in children with UPJ obstruction is still not fully understood and studies investigating the expression of this protein in urine have described different results. This may be due to different screening methods that have been used - some studies have examined this protein in the urine for bilateral UPJ obstruction, some reported biomarker concentrations in the renal pelvis, and some compared urinary levels of this protein in children with UPJ and children with upper tract dilation without obstruction.

In a study by Madsen et al. ${ }^{29}$, urinary EGF levels were significantly higher in the preoperative UPJ obstruction 
Table 3. Biomarkers and results of clinical studies.

\begin{tabular}{|c|c|c|c|}
\hline Urinary biomarker & $\begin{array}{l}\text { Difference in level } \\
\text { for operated and } \\
\text { healthy without } \\
\text { dilatation }\end{array}$ & $\begin{array}{l}\text { Difference in } \\
\text { level for operated / } \\
\text { dilatation without } \\
\text { obstruction }\end{array}$ & $\begin{array}{l}\text { Drop in postopera- } \\
\text { tive levels }\end{array}$ \\
\hline neutrophil gelatinase-associated lipocalin (NGAL) & $+(6-13)$ & $+(10,12)$ & $+(9,12,13)$ \\
\hline monocyte chemotactic peptide-1 (MCP1) & $+(6,9,28-31)$ & $+(9,28,30,32)$ & $+(31)$ \\
\hline transforming growth factor $\beta 1$ (TGF $\beta 1$ ) & $+(23-25) /-(6,26)$ & $+(27)$ & $+(24,25) /-(27)$ \\
\hline interleukin 6 (IL-6) & $+(6,40)$ & ND & ND \\
\hline carbohydrate antigen 19-9 (CA19-9) & $+(20-22)$ & $+(21)$ & $+(21,22)$ \\
\hline epidermal growth factor (EGF) & $+(29,31) /-(25)$ & $+(33,35)$ & $+(25,29,31)$ \\
\hline kidney injury molecule 1 (KIM1) & $+(7,9,12) /-(10)$ & $+(12,33) /-(34)$ & ND \\
\hline antimicrobial peptides $($ AMPs $) \times$ B defense $1(\mathrm{BD} 1)$ & $+(40)$ & ND & $+(40)$ \\
\hline cathelicidin (LL37) & ND & ND & $-(40)$ \\
\hline $\begin{array}{l}\text { hepatocarcinoma-intestine-pancreas/pancreatitis-associated } \\
\text { protein (HIP/PAP) }\end{array}$ & $+(40)$ & ND & $+(40)$ \\
\hline $\begin{array}{l}\text { Chemokine (C-C motif) ligand } 5 \text { (CCL5) also known as } \\
\text { RANTES (regulated upon activation, normal T cell } \\
\text { expressed and presumably secreted) }\end{array}$ & $+(29,30)$ & ND & $+(29) /-(30)$ \\
\hline $\mathrm{N}$-acetyl- $\beta$-D-glucosaminidase (NAG) & ND & $+(38,39)$ & ND \\
\hline prostaglandin reductase 1 (PTGR1) & $+(41)$ & ND & ND \\
\hline ficolin 2 (FCN2) & $+(41)$ & ND & ND \\
\hline quinolinate phosphoribosyl transferase (QPRT) & $+(41)$ & ND & ND \\
\hline $\begin{array}{l}\text { immunoglobulin superfamily containing leucine-rich repeat } \\
\text { protein (ISLR) a vascular cell adhesion molecule } 1 \\
\text { (VCAM1) }\end{array}$ & $+(41)$ & ND & ND \\
\hline
\end{tabular}

(+) significant difference between groups, (-) difference not found, (ND) evaluation not done

group compared to the healthy control group. According to Mohammadjafari et al. ${ }^{33}$, the urinary level of this biomarker was demonstrably increased in operated children before the operation compared to patients with upper tract dilation without obstruction treated conservatively. In contrast, Grandaliano et al..$^{31}$ pointed to demonstrably lower urinary concentrations in operated patients compared to healthy children and according to Li et al. ${ }^{35}$ also significantly lower levels compared to the observed patients with upper tract dilation without obstruction. Taha et al. ${ }^{25}$ found no difference between operated patients and healthy controls. Madsen et al. ${ }^{29}$, Taha et al. ${ }^{25}$, and Grandaliano et al. ${ }^{31}$ assessed the development of EGF urinary concentrations after pyeloplasty; their findings showed, postoperative values decreased significantly between two and four months after the operation.

\section{CCL5/RANTES}

Chemokine ligand 5 is a protein, also known as RANTES (regulated on activation, normal T cell expressed and secreted), which is classified as a chemotactic cytokine or chemokine. It plays an active role in the aggregation of leukocytes into sites of inflammation, is a key regulator of immune cell movement in various types of kidney disease, such as nephropathy and glomerulonephritis of various etiologies, chronic renal insufficiency, kidney transplant rejection, renal carcinoma, and lastly kidney damage and renal obstruction (Krensky et al. ${ }^{36}$ ).

Three studies evaluated CCL5 / RANTES as a promising biomarker in the diagnosis of UPJ obstruction. Madsen et al. ${ }^{29}$ and Taranta-Janusz et al. ${ }^{30}$ noted a signifi- cant difference in the concentration of this protein in the urine obtained from the renal pelvis of operated children compared with healthy children. This difference was also observed postoperatively in the work of Madsen et al. ${ }^{29}$ but was not reported in Taranta-Janusz et $\mathrm{al}^{30}$.

\section{NAG}

N-acetyl-beta-D-glucosaminidase is an enzyme produced by the lysosomes of proximal renal tubule cells. In healthy people, there is very little in the urine. Due to its high molecular weight, it cannot be filtered by glomeruli, and therefore its concentration in urine increases when the renal tubules are damaged ${ }^{37}$.

Two studies ${ }^{38,39}$ reported demonstrably elevated concentrations of this protein in a preoperative UPJ obstruction group compared to a group of conservatively treated patients with upper tract dilation without obstruction. Taha et al. ${ }^{39}$ pointed to significantly higher urinary NAG levels in younger children compared to older ones.

\section{Other potential biomarkers according to recent studies}

$\mathrm{Yu}$ et al. ${ }^{6}$ investigated the correlation of interleukin-6 (IL6), neutrophil gelatinase-associated lipocalin (NGAL), monocyte chemoattractant protein-1 (MCP1), and transforming growth factor- $\beta 1$ (TGFB1) levels with renal impairment in patients with unilateral and bilateral UPJ obstruction. Urinary NGAL, MCP1, and IL6 concentrations were significantly elevated in patients with UPJ obstruction compared to control healthy children, patients with bilateral UPJ obstruction having demonstrably higher urinary IL6, NGAL, and MCP1 levels compared 
to controls and patients with unilateral UPJ obstruction. The combination of NGAL and MCP1 slightly increased the predictive value of these biomarkers. According to this study, NGAL and MCP1 were found to be promising biomarkers for monitoring pediatric patients with bilateral UPJ obstruction.

Gupta et al. ${ }^{40}$ compared the concentrations of AMP biomarkers - HIP / PAP, BD-1, LL-37, and NGAL in patients with UPJ obstruction with healthy controls. They demonstrated significantly increased levels of HIP / PAP and BD-1 in patients with UPJ obstruction and subsequently a significant decrease in these markers after pyeloplasty, with urine samples being collected for an average of 27.4 months after surgery. The BD-1 value then did not differ in any way from the value measured in the group of healthy controls. These biomarkers could serve as markers of the success of surgical intervention.

Devarakonda et al. ${ }^{41}$ compared protein levels in patients with UPJ obstruction and in healthy controls who were first examined by mass spectrometry and then by quantitative ELISA. The final order of prevalence of 5 proteins from a panel of previously unknown biomarkers in patients with UPJ obstruction was PTGR1> FCN2> QPRT> ISLR> VCAM1. If these proteins were tested together, they could reliably distinguish pediatric patients with UPJ obstruction from those without obstruction.

Results of the clinical studies are summarised in Table 3.

\section{CONCLUSIONS}

To date, several potential biomarkers have been identified and investigated that could be useful in both the diagnosis and treatment of upper urinary tract obstruction in children in clinical practice. Clinical studies have yielded potentially promising results. However, a number of investigations have reached ambiguous or conflicting conclusions. This may be due to, for example, the heterogeneity of the selected population, different evaluation criteria, extremely broad design of individual studies, the large age range of patients in the cohort, especially in elderly patients. last but not least, short follow-up is a common problem in studies. It is necessary to carry out prospective, ideally multicenter studies with a large sample of patients using a strictly designed study and a sufficiently long follow-up time to be able to come to valid conclusions apropos the clinical role of biomarkers in the non-invasive diagnosis of UPJ obstruction. These requirements were fulfilled by just one study presented by Fendereski et. al. ${ }^{14}$.

Valid and reliable biomarkers would be helpful not only in the diagnosis of congenital obstructive uropathies but also in distinguishing between hydronephrosis with and without obstruction. The possibility of using biomarkers to evaluate the success of surgical treatment is also interesting, however, the available data are insufficient for transfer to clinical practice.

In the future, urinary biomarkers could become an important clinical tool in the algorithm of care for chil- dren with UPJ obstruction. Unfortunately, so far, urinary biomarkers cannot be used in the current urological care of children.

\section{Search strategy and selection criteria}

Our research strategy was aimed at evaluating clinical studies on the role of biomarkers in children with UPJ obstruction. Scientific articles from 2000 to 2021 were searched using the PubMed and Web of Science databases. All searches were up to date as of March 2021. The search terms used included "hydronephrosis", "obstruction", "pelviureteral junction" and "biomarkers". Only English language papers were reviewed. Accepted were articles referring to the pediatric population only. We manually added articles published before 2000 by Koprowski et al. ${ }^{15}$, Vestergaard et al. ${ }^{16}$, Aoki et al. ${ }^{17}$, and Palmer et al. ${ }^{26}$ based on their clinical importance.

\section{ABBREVIATIONS}

UPJ, ureteropelvic junction; US, ultrasound; UUTD, upper urinary tract dilation; 99mTc-MAG 3, technetium mercaptoacetyltriglycine; VCUG, voiding cystourethrography; UUT, upper urinary tract; ELISA, human sandwich enzyme-linked immunosorbent assay; NGAL, neutrophil gelatinase-associated lipocalin; MCP1, monocyte chemotactic peptide-1; TGF $\beta 1$, transforming growth factor $\beta 1$; IL-6, interleukin 6; CA19-9, carbohydrate antigen 19-9; EGF, epidermal growth factor; KIM1, kidney injury molecule 1; AMPs, antimicrobial peptides; BD1, B defense 1; LL37, cathelicidin; HIP/PAP, hepatocarcinoma-intestine-pancreas/pancreatitis-associated protein; CCL5, Chemokine (C-C motif) ligand 5; RANTES, regulated upon activation, normal $\mathrm{T}$ cell expressed and presumably secreted; NAG, N-acetyl- $\beta$-D-glucosaminidase; PTGR1, prostaglandin reductase 1; FCN2, ficolin 2; QPRT, quinolinate phosphoribosyltransferase; VCAM1, vascular cell adhesion molecule 1; ISLR, immunoglobulin superfamily containing leucine-rich repeat protein.

Acknowledgement: The study was supported by the Internal Grant of Palacký University IGA LF 2020-046.

Author contributions: All authors contributed to the study conception and design. ZS: manuscript writing, litearature search; HF, JS, OS: manuscript revision, critical reading, VS: manuscript revision, critical reading, written English correction, and prepared submission. All authors read and approved the final manuscript.

Conflict of interest statement: The authors state that there are no conflicts of interest regarding the publication of this article.

\section{REFERENCES}

1. Radmayr C, Bogaert G, Dogan HS, Kočvara R, Nijman JM, Stein R, Tekgül S, 't Hoen LA, Quaedackers J, Silay MS, Undre S. EAU Guidelines on Pediatric Urology. In: European Association of Urology Guidelines, 2018 edition. European Association of Urology, 2018, p. 58. ISBN 978-94-92671-01-1. 
2. Peters C, Chevalier R. Congenital urinary obstruction: Pathophysiology and clinical evaluation. In: Campbell-Walsh Urology: Pediatric urology [online]. Elsevier, 2015 [vid. 2021-02-02]. Available from: https://expertconsult.inkling.com/read/wein-campbellwalshurology-pediatric-urology-1st/chapter-14/clinical

3. Lebowitz, RL, Griscom NT. Neonatal hydronephrosis: 146 cases. Radiol Clin North Am 1977;15:49.

4. Radmayr C, Bogaert G, Dogan HS, Nijman JM, Rawashdeh YFH, Silay MS, Stein R, Tekgül S. EAU Guidelines on Pediatric Urology. In: European Association of Urology [online]. Uroweb, 2021 [vid. 202102-24]. Available from: https://uroweb.org/guideline/paediatricurology/

5. Biomarkers Definitions Working Group. Biomarkers and surrogate endpoints: preferred definitions and conceptual framework. Clin Pharmacol Ther 2001;69:89-95.

6. Yu L, Zhou L, Li Q, Wu B, Brooks JD, Sun H. J Elevated urinary lipocalin-2, interleukin- 6 and monocyte chemoattractant protein-1 levels in children with congenital ureteropelvic junction obstruction Pediatr Urol 2019;15:44.e1-7.

7. Bieniaś B, Sikora P. Potential novel biomarkers of obstructive nephropathy in children with hydronephrosis. Dis Markers 2018;2018:1015726.

8. Gupta S, Jackson AR, DaJusta DG, McLeod DJ, Alpert SA, Jayanthi VR, McHugh K, Schwaderer AR, Becknell B, Ching CB. Urinary antimicrobial peptides: potential novel biomarkers of obstructive uropathy. J Pediatr Urol 2018;14:238.e1-6.

9. Karakus S, Oktar T, Kucukgergin C, Kalelioglu I, Seckin S, Atar A, Ander H, Ziylan O. Urinary IP- 10, MCP-1, NGAL, cystatin-C, and KIM-1 levels in prenatally diagnosed unilateral hydronephrosis: the search for an ideal biomarker. Urology 2016;87:185-92.

10. Noyan A, Parmaksiz G, Dursun H, Euer SS, Anarat R, Cengiz N. Urinary NGAL, KIM-1 and L-FABP concentrations in antenatal hydronephrosis. J Pediatr Urol 2015;11:249.e1-6.

11. Cost NG, Noh PH, Devarajan P, Ivancic V, Reddy PP, Minevich E, Bennett M, Haffner C, Schulte M, DeFoor WR Jr. Urinary NGAL levels correlate with differential renal function in patients with ureteropelvic junction obstruction undergoing pyeloplasty. J Uro 2013;190:1462-7.

12. Wasilewska A, Taranta-Janusz K, Dębek W, Zoch-Zwierz W, Kuroczycka-Saniutycz E. KIM- 1 and NGAL: new markers of obstructive nephropathy. Pediatr Nephrol 2011;26:579-86.

13. Madsen MG, Nørregaard R, Palmfeldt J, Olsen LH, Frøkiaer J, Jørgensen TM. Urinary NGAL, cystatin C, $\beta 2$-microglobulin, and osteopontin significance in hydronephrotic children. Pediatr Nephrol 2012;27:2099-106.

14. Fendereski K, Nabighadim A, Seyedtabib M, Daryabari SS, HaghiAshtiani MT, Kajbafzadeh AM. Comparing predictive values of carbohydrate antigen 19-9, neutrophil gelatinase-associated lipocalin, and kidney injury molecule-1 in 161 patients with ureteropelvic junction obstruction. Pediatr Nephrol 2021;36(3):631-38

15. Koprowski H, Herlyn M, Steplewski Z, Sears HF. Specific antigen in serum of patients with colon carcinoma. Science 1981;212:53e5.

16. Vestergaard EM, Wolf H, Orntoft TF. Increased concentrations of genotype-interpreted $\mathrm{Ca}$ 19-9 in urine of bladder cancer patients mark diffuse atypia of the urothelium. Clin Chem 1998;44:197e204

17. Aoki D, Nomata K, Kanda S, Sawase K, Kanetake H, Saito Y, Tsuda N. A case of pyonephrosis caused by ureteral stones with elevated serum levels of CA19-9. Hinyokika Kiyo 1999;45: 629e32.

18. Suzuki K, Muraishi O, Tokue A. The correlation of serum carbohydrate antigen 19-9 with benign hydronephrosis. J Urol 2002;167:16e20.

19. Taki T, Honda N, Yamada Y, Hibi H, Mitsui K, Matsuura O, Yoshikawa K. CA19-9-producing transitional cell carcinoma of the renal pelvis: a case report. Hinyokika Kiyo 2001;47:191e4

20. Nabavizadeh B, Khorramirouz R, Amini E, Pishgar F, Hojjat A, Kajbafzadeh AM. Value of urinary carbohydrate antigen 19-9 to predict failure of conservative management in children with ureteropelvic junction obstruction. J Pediatr Surg 2019;54:1650-3.

21. Atar A, Oktar T, Kucukgergin C, Kalelioglu I, Seckin S, Ander H, Ziylan $\mathrm{O}$, Kadioglu TC. The roles of serum and urinary carbohydrate antigen 19-9 in the management of patients with antenatal hydronephrosis. J Pediatr Urol 2015;11:133.e1-5.
22. Kajbafzadeh AM, Elmi A, Talab SS, Emami H, Esfahani SA, Saeedi P. Urinary and serum carbohydrate antigen 19-9 as a biomarker in ureteropelvic junction obstruction in children. J Urol 2010;183:2353-60.

23. Merrikhi A, Bahraminia E. Association of urinary transforming growth factor- $\beta 1$ with the ureteropelvic junction obstruction. Adv Biomed Res 2014;3:123.

24. Sager C, Lopez JC, Duran V, Burek C, Perazzo E. Transforming growth factor-beta1 in congenital ureteropelvic junction obstruction: diagnosis and follow-up. Int Braz J Urol 2009;35:315-23; discussion 323-5.

25. Taha MA, Shokeir AA, Osman HG, Abd El-Aziz Ael-A, Farahat SE. Pelvi-ureteric junction obstruction in children: the role of urinary transforming growth factor-beta and epidermal growth factor. BJU Int 2007;99:899-903.

26. Palmer LS, Maizels M, Kaplan WE, Filrit CF, Cheng EY. Urine levels of transforming growth factor-beta 1 in children with ureteropelvic junction obstruction. Urology 1997;50:769-73.

27. El-Sherbiny MT, Mousa OM, Shokeir AA, Ghoneim MA. Role of urinary transforming growth factor-beta1 concentration in the diagnosis of upper urinary tract obstruction in children. J Urol 2002;168:1798800.

28. Sadeghi-Bojd S, Alijani E, Mahdavian MS. Mean urinary cytokine MCP-1 in children with urinary tract obstruction and healthy children. Nephro-Urol Mon 2018;10:e63607.

29. Madsen MG, Nørregaard R, Palmfeldt J, Olsen LH, Frøkiaer J, Jørgensen TM. Epidermal growth factor and monocyte chemotactic peptide-1: potential biomarkers of urinary tract obstruction in children with hydronephrosis. J Pediatr Urol 2013;9:838-45.

30. Taranta-Janusz K, Wasilewska A, Dębek W, Waszkiewicz-Stojda M. Urinary cytokine profiles in unilateral congenital hydronephrosis. Pediatr Nephrol 2012;27:2107-13.

31. Grandaliano G, Gesualdo L, Bartoli F, Ranieri E, Monno R, Leggio A, Pradies G, Caldarulo E, Infante B, Schena FP. MCP- 1 and EGF renal expression and urine excretion in human congenital obstructive nephropathy. Kidney Int 2000;58:182-92.

32. Mohammadjafari H, Rafiei A, Mousavi SA, Alaee A, Yeganeh Y. Role of urinary levels of endothelin-1, monocyte chemotactic peptide-1, and $\mathrm{N}$-acetyl glucosaminidase in predicting the severity of obstruction in hydronephrotic neonates. Korean J Urol 2014;55:670-6.

33. Mohammadjafari $H$, Rafiei A, Kosaryan M, Yaganeh $Y$, Hosseinimehr SJ. Determination of the severity of ureteropelvic junction obstruction using urinary epidermal growth factor and kidney injury molecule 1 levels. Biomark Med 2014;8:1199-206.

34. Gerber C, Harel M, Lynch ML, Herbst KW, Ferrer FA, Shapiro LH. Proximal tubule proteins are significantly elevated in bladder urine of patients with ureteropelvic junction obstruction and may represent novel biomarkers: a pilot study. J Pediatr Urol 2016;12:120.e1-7.

35. Li Z, Zhao Z, Liu X, Su Z, Shang X, Wen J. Prediction of the outcome of antenatal hydronephrosis: significance of urinary EGF. Pediatr Nephrol 2012;27:2251-9.

36. Krensky AM, Ahn YT. Mechanisms of disease: regulation of RANTES (CCL5) in renal disease. Nat Clin Pract Nephrol 2007;3(3):164-70.

37. Andreucci M, Faga T, Pisani A, Perticone M, Michael A. The ischemic/ nephrotoxic acute kidney injury and the use of renal biomarkers in clinical practice. Eur J Intern Med 2017;39:1-8.

38. Shokeir AA, Taha MA. Role of urinary tubular enzymes in evaluation of children with ureteropelvic junction narrowing under conservative management. Urology 2009;73:1016-20.

39. Taha MA, Shokeir AA, Osman HG, Abd El-Aziz Ael-A, Farahad SE. Obstructed versus dilated nonobstructed kidneys in children with congenital ureteropelvic junction narrowing: role of urinary tubular enzymes. J Urol 2007;178:640-6.

40. Gupta S, Nicassio L, Junquera GY, Jackson AR, Fuchs M, McLeod D, Alpert S, Jayanthi VR, DaJusta D, McHugh KM, Becknell B, Ching CB. Impact of successful pediatric ureteropelvic junction obstruction surgery on urinary HIP/PAP and BD-1 levels. J Pediatr Urol 2020;16(5):592.e1-592.e7.

41. Devarakonda CKV, Shearier ER, Hu C, Grady J, Balsbaugh JL, Makar $\mathrm{JH}$, Ferrer FA, Shapiro LH. A novel urinary biomarker protein panel to identify children with ureteropelvic junction obstruction - A pilot study. J Pediatr Urol 2020;16(4):466.e1-466.e9. 